Яхонтов Д.А., Останина Ю.О.

ФГБОУ ВО «Новосибирский государственный медицинский университет» Минздрава России

\title{
ISCHEMIA trial. The relationship between medical and interventional approach to stable ischemic heart disease treatment. Myocardial ischemia with non-obstructive coronary arteries (INOCA)
}

\author{
Yakhontov D.A., Ostanina Yu.O. \\ Novosibirsk State Medical University
}

\begin{abstract}
АННОТАЦИЯ
В в еден и е. Подходы к терапии стабильной ишемической болезни сердца (ИБС) долгое время являлись предметом дискуссий. Одно из первых и основополагающих исследований в вопросах терапии больных стабильной ИБC COURAGE показало преимущество рациональной медикаментозной терапии над чрескожным коронарным вмешательством, однако высокая распространенность и медико-социальная значимость ИБС диктует необходимость дальнейшей разработки проблемы взаимоотношения консервативных и интервенционных подходов в лечении данного заболевания, чему, в частности, было посвящено недавно завершенное крупномасштабное исследование ISCHEMIA. Еще одна актуальная проблема современной кардиологии - ишемия миокарда при необструктивном (<50 \% сужения просвета) поражении коронарных артерий (Ischemia with Non-Obstructive Coronary Arteries - INOCA), определяющемся примерно у 70 \% пациентов при ангиографическом исследовании коронарных сосудов.

Ц е л . Анализ имеющихся данных по ведению пациентов со стабильной ИБС на основе результатов исследования ISCHEMIA и обзор публикаций по проблеме INOCA.

P е з у л ь т а т ы . В исследовании ISCHEMIA частота первичной конечной точки (сердечно-сосудистая смерть, инфаркт миокарда (ИМ), остановка сердца с эффективной реанимацией, госпитализация в связи с хронической сердечной недостаточностью) составила 13.3 \% в группе рутинной инвазивной стратегии и 15.5 \% в группе консервативной стратегии ( $p=0.34)$. Частота основных вторичных конечных точек также значимо между группами не различалась. Качество жизни в группе инвазивного лечения было выше только у пациентов с наличием в начальном периоде приступов стенокардии. Субанализ исследования показал, что пограничный стеноз левой коронарной артерии (ЛКА) ассоциирован с негативным прогнозом, а инвазивная стратегия облегчает симптомы стенокардии. У женщин, участвовавших в исследовании ISCHEMIA, чаще отмечались приступы стенокардии, несмотря на менее обширное поражение коронарных артерий (КА) и менее тяжелые проявления ишемии, чем у мужчин. Среди пациентов со стабильной ИБС с умеренной или тяжелой ишемией и тяжелой хронической болезнью почек не было найдено доказательств преимущества первоначальной инвазивной стратегии в снижении риска смерти или нефатального инфаркта миокарда по сравнению с консервативной стратегией. Что касается ишемии при необструктивном поражении КА (INOCA), то последнее диагностируется по меньшей мере у одного из пяти пациентов, прошедших коронарографию. Это требует поиска новых диагностических методик, верификации факторов риска, причин и оптимальных подходов к лечению.

З а к л ю ч е и е. Результаты исследования ISCHEMIA продемонстрировали необходимость более тщательного отбора пациентов со стабильной ИБС для инвазивного лечения с учетом тяжести стенокардии и возможности
\end{abstract}

Поступила 04.03.2021

Принята 28.03.2021

Автор, ответственный за переписку

Останина Юлия Олеговна: ФГБОУ ВО «Новосибирский государственный медицинский университет» Минздрава России. 630091, г. Новосибирск, Красный просп., 52.

E-mail: julia679@yandex.ru
Received 04.03.2021

Accepted 28.03.2021

Corresponding author

Ostanina Yuliya Olegovna: Novosibirsk State Medical University, 52, Krasny Prospect, Novosibirsk, 630091, Russia.

E-mail: julia679@yandex.ru 
современной антиангинальной терапии. Ведение больных с ишемией миокарда на фоне необструктивного поражения КА следует осуществлять на основе Согласительного документа экспертов по проблеме INOCA (2020), в котором рассматриваются вопросы возникновения стенокардии, диагностики и лечения данного состояния.

Ключевъе слова: ишемическая болезнь сердца, необструктивное поражение коронарных артерий, исследование ISCHEMIA.

\section{ABSTRACT}

In tr o d u cti o n. Approaches to the stable coronary heart disease (CHD) treatment have been the subject to debate a long time. One of the first and fundamental studies in the treatment of stable coronary heart disease patients is the COURAGE trial, which showed the advantage of rational drug therapy in comparison with percutaneous intervention in such patients. However, the CHD high prevalence with medical and social significance necessitate the future consideration of the relationship between medical, that is conservative, and invasive approaches in treatment of this disease. It was particularly the focus of the recently completed multicentre ISCHEMIA trial. Another urgent problem of modern cardiology is myocardial ischemia in non-obstructive ( $<50 \%$ luminal occlusion) coronary arteries (INOCA) identified in approximately $70 \%$ of patients who underwent coronary angiography.

$\mathrm{Aim}$ of the $\mathrm{resear} \mathrm{ch}$. Analysis of the available data on the management of stable CHD patients based on the ISCHEMIA trial data and review of publications on the INOCA problem.

Results. In the ISCHEMIA trial, the occurrence rate of the primary outcome (cardiovascular death, myocardial infarction (MI), resuscitated cardiac arrest, hospitalization for chronic heart failure) was $13.3 \%$ in the routine invasive strategy group and $15.5 \%$ in the conservative strategy group $(p=0.34)$. The occurrence rate of the main secondary outcomes also did not differ between the groups significantly. Quality of life in the invasive group was higher only in patients who had angina at baseline. The study subanalysis demonstrated that borderline left coronary artery stenosis is associated with a poor prognosis, and an invasive strategy relieves the angina symptoms. Women who participated in the ISCHEMIA trial had a higher incidence of angina attacks, despite less extensive coronary arteries (CA) lesions and less severe ischemia manifestations than men. Among patients with stable CHD accompanied with moderate to severe ischemia and severe chronic kidney disease patients, no evidence for the benefit of the initial invasive strategy in reducing the risk of death or nonfatal myocardial infarction compared to the conservative strategy was found. As for ischemia in non-obstructive coronary arteries (INOCA), it is diagnosed in at least one in five patients who have undergone coronary angiography. This requires the search for new diagnostic methods, verification of risk factors, causes, and optimal treatment approaches.

C o n clus i o n. The ISCHEMIA trial data demonstrated the necessity for a more careful selection of patients with stable CHD for invasive treatment, taking into account the angina pectoris severity and modern antianginal therapy possibilities. Management of patients with myocardial ischemia accompanied by non-obstructive CA lesions should be carried out on the basis of the EAPCI Expert Consensus Document on Ischaemia with INOCA (2020) which discusses the genesis of angina, as well as the diagnosis and treatment of this condition.

Keywords: coronary heart disease, non-obstructive coronary arteries, ISCHEMIA trial.

\section{$\mathbb{B} \mathrm{BE}$ ДЕНЕ}

Ишемическая болезнь сердца (ИБС), несмотря на активное развитие как медикаментозных, так и хирургических методов лечения, остается основной причиной инвалидизации и смертности лиц трудоспособного возраста $[1,2]$. Вопрос о прогностической значимости реваскуляризации миокарда у пациентов со стабильной ИБС изучается достаточно давно, и в большинстве исследований показано, что плановая реваскуляризация не снижает риск инфаркта миокарда (ИМ) и смерти. В то же время установлено, что реваскуляризация миокарда более эффективно снижает тяжесть стенокардии, уменьшает потребность в антиангинальных средствах, улучшает переносимость физических нагрузок и повышает качество жизни в сравнении с только медикаментоз-

\section{INTRODUCTION}

Coronary heart disease (CHD), despite the active development of both medical and surgical methods of treatment, remains the main cause of disability and mortality in people of working age [1, 2]. The prognostic significance of myocardial revascularization in patients with stable CHD has been studied for a long time, and most studies have shown that elective revascularization does not reduce the risk of myocardial infarction (MI) and death. At the same time, it was found that myocardial revascularization more effectively reduces the severity of angina, decreases the need for antianginal agents, improves the tolerance of physical exertion and improves quality of life in comparison with only drug treatment, both over the short- and longterm horizon [3]. Another urgent problem of mo- 
ным лечением, как в краткосрочной, так и в долгосрочной перспективе [3]. Еще одной актуальной проблемой современной кардиологии является ишемия миокарда при необструктивном ( $<50$ \% сужения просвета) поражении коронарных артерий (Ischemia with Non-Obstructive Coronary Arteries - INOCA), определяющемся примерно у 70 \% пациентов при ангиографическом исследовании коронарных сосудов. INOCA может быть результатом вазоспазма, микроциркуляторных нарушений, гипертонии, аортального стеноза, анемии, кардиомиопатии, миокардита, сердечной недостаточности, аутоиммунных болезней, аномалии коронарных сосудов и т.д. $[4,5]$.

\section{ЦЕЛЬ ИССЛЕДОВАНИЯ}

Анализ имеющихся данных по ведению пациентов со стабильной ИБС на основе результатов исследования ISCHEMIA и обзор публикаций по проблеме INOCA.

\section{РЕЗУЛЬТАТЫ И ОБСУЯКЛЕНИЕ}

Одним из первых и основополагающих исследований в вопросах подхода к терапии больных стабильной ИБС является исследование COURAGE, проведенное в 50 клинических центрах США и Канады в 1999-2004 гг. с включением 2287 больных. В данном исследовании сопоставлялись инвазивная (чрескожное коронарное вмешательство - ЧКВ) тактика ведения пациентов $(n=1149)$ и агрессивная медикаментозная терапия ( $n=1138)$. По результатам исследования продемонстрировано ведущее значение медикаментозной вторичной профилактики, что согласуется с современными рекомендациями. Не обнаружено достоверных различий частоты осложнений между группами ЧКВ и оптимальной медикаментозной терапии. Кумулятивная частота первичных событий за 4.6 года составила 19.0 \% в группе ЧКВ и 18.5 \% в медикаментозной группе $(p=0.62)$. Таким образом, было показано, что ЧКВ в дополнение к медикаментозной терапии как начальная стратегия у больных стабильной ИБС не уменьшает риск смерти, ИМ или сердечно-сосудистых событий $[6,7]$. Кроме того, оценивались шесть заранее определенных факторов риска: систолическое артериальное давление, холестерин липопротеинов низкой плотности, курение, физическая активность, диета и индекс массы тела. Оказалось, что чем больше факторов риска контролируется, тем выше вероятность выживания пациентов, и поэтому больным стабильной ИБС необходимо использование dern cardiology is myocardial ischemia with nonobstructive $(<50 \%$ occlusion) lesion of the coronary arteries (Ischemia with Non-Obstructive Coronary Arteries - INOCA) which is found in about 70\% of patients who underwent the coronary angiography. INOCA can be the result of vasospasm, microcirculatory disorders, hypertension, aortic stenosis, anemia, cardiomyopathy, myocarditis, heart failure, autoimmune diseases, coronary vascular abnormalities, etc. $[4,5]$.

\section{AIM OF THE RESEARCH}

Analysis of available data on the management of patients with stable CHD based on the ISCHEMIA trial data and review of publications on the INOCA problem.

\section{RESULTS AND DISCUSSION}

One of the first and fundamental studies of the approach to the treatment of patients with stable CHD is the COURAGE trial conducted in 19992004 in 50 clinical centers in the United States and Canada with 2287 patients included. In this study, the invasive (percutaneous coronary intervention - PCI) strategy $(n=1149)$ and aggressive drug therapy ( $n=1138$ ) were compared. According to the trial results, the crucial importance of drug secondary prevention was demonstrated, which is consistent with current guidelines. There were no significant differences in the frequency of complications between the PCI and drug therapy groups. The cumulative primary events rate for 4.6 years was $19.0 \%$ in the PCI group and $18.5 \%$ in the medical therapy group $(p=0.62)$. Thus, it has been shown that the PCI in addition to drug therapy as an initial strategy in patients with stable CHD does not reduce the risk of death, MI, or cardiovascular events $[6,7]$. In addition, six pre-determined risk factors were evaluated: systolic blood pressure, low-density lipoprotein cholesterol, current smoking, physical activity, diet, and the body mass index. It turned out that the more risk factors are controlled, the higher the probability of survival, and therefore, patients with stable CAD need more effective strategies to achieve comprehensive control of risk factors $[6,7]$.

The largest multicentre randomized clinical ISCHEMIA trial (conducted in 37 countries, and its results were reported in 2019 at the scientific session of the American Heart Association) included patients with verified severe or moderate ischemia (5179 of 8518 participants; average age 64 years; $23 \%$ women). In modern clinical practice, almost 
более эффективных стратегий для достижения всестороннего контроля факторов риска [6, 7].

В крупнейшее многоцентровое рандомизированное клиническое исследование ISCHEMIA, проводившееся в 37 странах, результаты которого были доложены в 2019 г. на научной сессии Американской ассоциации сердца, включались пациенты с доказанной ишемией тяжелой или умеренной степени (5179 из 8518 участников; средний возраст 64 года; 23 \% женщин). В рамках современной клинической практики почти $75 \%$ таких пациентов проводится реваскуляризация миокарда. Не включались в исследование больные со стенозом ствола левой коронарной артерии (ЛКА) $>50$ \%, фракцией выброса $<35 \%$, хронической сердечной недостаточностью (XCH) III-IV функционального класса, инфарктом миокарда, чрескожным вмешательством или аортокоронарным шунтированием в течение предшествующего года, скоростью клубочковой фильтрации < 30 мл/мин, тяжелой стенокардией. У 34 \% пациентов клиники стенокардии не было, у $44 \%$ приступы возникали несколько раз в месяц, у 22 \% - ежедневно либо еженедельно. Пациенты были рандомизированы в две группы рутинной инвазивной стратегии в сочетании с оптимальной медикаментозной терапией (OMT) $(n=2588)$ и только ОМТ $(n=2591)$. В группе консервативной терапии коронарная ангиография проводилась только в случае неэффективности медикаментозной терапии. Период наблюдения составил 3.3 года (рис. 1).

Частота первичной конечной точки (сердечно-сосудистая смерть, ИМ, остановка сердца с эффективной реанимацией, госпитализация в связи с ХCH) составила 13.3 \% в группе инвазивной стратегии и $15.5 \%$ - в группе консервативной терапии ( $p=0.34)$ [8]. Инвазивная стратегия увеличивала риск перипроцедурных осложнений, при этом снижая примерно на $2 \%$ риск неблагоприятных событий в дальнейшем (после первых 6 мес наблюдения). Частота основных вторичных конечных точек (сердечнососудистая смертность + ИМ, смерть от всех причин, перипроцедуральный ИМ, спонтанный ИМ) также достоверно между группами не различалась. Качество жизни в группе инвазивного лечения было выше только у пациентов с исходным наличием симптомов стенокардии. Было сделано заключение о необходимости более тщательного отбора пациентов со стабильной ИБС для инвазивного лечения, принимая во внимание тяжесть стенокардии и возможности антиангинальной терапии $[9,10]$.
$75 \%$ of such patients undergo myocardial revascularization. Patients with left main coronary artery stenosis > 50\%, left venticular ejection fraction $<35 \%$, NYHA class III-IV heart failure, myocardial infarction, percutaneous intervention or coronary artery bypass graft surgery within the previous 12 months, glomerular filtration rate $<30 \mathrm{ml} /$ min, severe angina pectoris were not included in the study. In $34 \%$ of patients did not have angina symptoms, $44 \%$ had attacks several times a month, $22 \%$ had daily or weekly attacks. The patients were randomized into two groups - an invasive strategy combined with optimal medical therapy (OMT) ( $n=2588)$, and only OMT $(n=2591)$. In the conservative therapy group, coronary computed tomography angiography was performed only if the drug therapy was ineffective. The follow-up period was 3.3 years (Fig. 1).

The occurrence rate of the primary outcome (cardiovascular death, MI, resuscitated cardiac arrest, hospitalization for chronic heart failure) was $13.3 \%$ in the invasive strategy group and $15.5 \%$ in the conservative (medical) strategy one $(p=0.34)$ [8]. The invasive strategy increased the risk of periprocedural complications, while reducing the risk of the adverse cardiac events in the future by about 2\% (after the first 6 months of follow-up). The occurrence rate of the main secondary outcomes (cardiovascular mortality $+\mathrm{MI}$, death from all causes, periprocedural MI, spontaneous MI) also did not differ significantly between the groups. Quality of life in the invasive group was higher only in patients who had angina symptoms at baseline. It was concluded that more careful selection of patients with stable CHD for invasive treatment is necessary, taking into account the severity of angina and the possibilities of antianginal therapy $[9,10]$.

The subanalysis of the ISCHEMIA trial showed that borderline left coronary artery (LCA) stenosis is associated with a poor prognosis, although an invasive strategy alleviates angina symptoms. A comparative analysis of the results in 962 patients with LCA stenosis 25-49\% and in 2737 patients with LCA stenosis $<25 \%$ was carried out. Patients with stenosis $25-49 \%$ had a more severe ischemia and more often three-vessel disease. They, in comparison with patients with LCA stenosis $<25 \%$, had a higher risk of adverse outcomes over the next four years. Evaluation of the treatment results did not reveal differences depending on the use of an invasive or conservative strategy for primary and major secondary outcomes, however, the invasive strategy 
8518 включенных пациентов

8518 patients included

3783 (73.0 \%) прошли ККТА / underwent CСТА

1396 (27.0 \%) не прошли ККТА / did not undergo ССТА

575 имели низкую СКФ / had low GFR

700 была известна анатомия КА / had known CA anatomy

121 имели другую причину / had another cause

3339 были исключены / were excluded

1350 не имели умеренной или тяжелой ишемии по данным стресс-тестов / did not have moderate or severe ischemia according to the stress tests

1218 не имели обструктивной ИБС / did not have obstructive CHD

434 имели поражение ЛКА / had LCA lesion

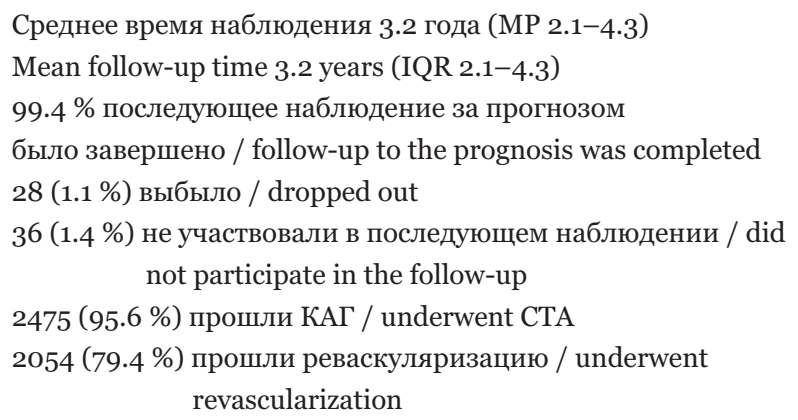

Рис. 1. Дизайн исследования ISCHEMIA (ККТА - компьютерная коронарная томографическая ангиография; СКФ - скорость клубочковой фильтрации; ЛКА - левая коронарная артерия; КА - коронарная артерия; КАГ - компьютерная ангиография; МP - межквартильный размах)

Fig. 1. ISCHEMIA trial design (CCTA - coronary computed tomography angiography; GFR - glomerular filtration rate; LCA - left coronary artery; CA — coronary artery; CTA - computed tomography angiography; $\mathrm{IQR}$ - interquartile range)

Субанализ исследования ISCHEMIA показал, что пограничный стеноз ЛКА ассоциируется с негативным прогнозом, хотя инвазивная стратегия облегчает симптомы стенокардии. Проведен сравнительный анализ результатов у 962 пациентов со стенозом ЛКА 25-49 \% и у 2737 пациентов со стенозом ЛКА $<25 \%$. Больные со стенозом 25-49 \% имели более высокую степень ишемии и чаще 3-сосудистое поражение. У них же, в сравнении с пациентами со стенозом ЛКА $<25 \%$, был более высокий риск неблагоприятных исходов в течение последующих четырех лет. Оценка результатов лечения не выявила различий в зависимости от использования инвазивной либо консервативной стратегии для первичных и основных вторичных исходов, однако инвазивная стратегия была связана со снижением непроце- was associated with a decrease in non-procedural MI, the more significant improvement in the quality of life, but, at the same time, with an increase in the incidence rate of $\mathrm{MI}$ in cases of prior intervention [11].

The ISCHEMIA study also determined the rate of achievement of the targets for low-density lipoprotein cholesterol (LDL-C) $(<70 \mathrm{mg} / \mathrm{dl})$ and systolic blood pressure (SBP) $(<140 \mathrm{~mm} \mathrm{Hg})$. The target level of LDL-C was reached by $35 \%$, and the target level of SBP - by $65 \%$ of participants. A year later, the number of participants with the target LDL-C increased to $52 \%$, and with the target SBP - to $75 \%$. The adjusted odds of achieving the target LDL-C level after one year were higher in the older age group (odds ratio (OR) 1.11; 95\% confidence interval (CI) 1.03-1.20 for 10 years of life), with lower baseline 
дурального ИМ, более значительным повышением качества жизни, но в то же время с увеличением частоты ИМ на фоне вмешательства [11].

Также в исследовании ISCHEMIA была определена частота достижения целевых показателей холестерина липопротеинов низкой плотности (ХС-ЛПНП) (<70 мг/дл) и систолического артериального давления (САД) (<140 мм рт. ст.). Целевого уровня ХС-ЛПНП достигли $35 \%$, а целевого уровня САД -65 \% участников. Через год количество участников с целевыми показателями ХС-ЛПНП увеличилось до 52 \%, а с целевым САД - до 75 \%. Скорректированные шансы достижения целевого уровня ХС-ЛПНП через год были выше в более старшей возрастной группе (отношение шансов (ОШ) 1.11; 95\% доверительный интервал (ДИ) 1.03-1.20 для 10 лет жизни), при более низком исходном уровне ХС-ЛПНП (ОШ 1.19; 95\% ДИ 1.17-1.22 при уровне 10 мг/дл) и при высокоинтенсивном использовании статинов (ОШ 1.30; 95\% ДИ 1.12-1.51). У женщин оказалось меньше шансов, чем у мужчин, достичь целевого уровня ХС-ЛПНП (ОШ о.68; 95\% ДИ 0.58-0.80) в течение года. Скорректированные шансы достижения целевого уровня САД через год были выше при более низком исходном САД (ОШ 1.27; 95\% ДИ 1.22-1.33) и у проживающих в странах Северной Америки (ОШ 1.35; 95\% ДИ 1.04-1.76).

В ходе вторичного анализа ISCHEMIA оценивались исходные характеристики пациентов со стабильной ИБС (77 \% - мужчины). Стенокардия оценивалась с помощью Сиэтлского опросника боли. У женщин чаще регистрировался стеноз сосудов < 50 \% (353 из 1022 (34.4 \%) против 378 из 3353 (11.3 \%) у мужчин). При этом женщины отличались более высоким классом стенокардии, чем мужчины (медиана (межквартильный размах) по Сиэтлскому опроснику боли 80 (70-10о) против 90 (70-100)), но у них была менее тяжелая ишемия при визуализирующих стресс-тестах (383 пациента из 919 (41.7 \%) против 1361 из 2972 (45.9\%) с тяжелой ишемией; 386 пациентов из 919 (42.0 \%) против 1215 из 2972 (40.9 \%) с умеренной ишемией; 150 пациентов из 919 (16.4\%) против 394 из 2972 (13.3 \%) с легкой ишемией или без нее). Кроме того, у женщин было менее обширное поражение сосудов. Так, трехсосудистое поражение имело место у 36 \% женщин и у $47 \%$ мужчин; двухсосудистое поражение - у 32 и $31 \%$ соответственно; однососудистое поражение - у 31 \% женщин и 22 \% мужчин. Женский пол был независимо связан с большей частотой приступов стенокардии (ОШ 1.41; 95\% ДИ 1.13-1.76).
LDL-C levels (OR 1.19; 95\% CI 1.17-1.22 at $10 \mathrm{mg} / \mathrm{dl}$ ), and with high-intensity statin use (OR 1.30; 95\% CI 1.12-1.51). Women were less likely than men to reach the target LDL-C level (OR o.68; 95\% CI 0.58-0.80) within a year. The adjusted odds of achieving the target level of SBP after one year were higher for the lower baseline SBP (OR 1.27; 95\% CI 1.22-1.33) and for those living in North America (OR 1.35; 95\% CI 1.04-1.76).

The secondary ISCHEMIA analysis evaluated the baseline characteristics of patients with stable CHD (of them $77 \%$ men). Angina was assessed using the Seattle Pain Questionnaire. Women were more likely to have vascular stenosis $<50 \%$ (353 out of 1022 (34.4\%) versus 378 out of 3353 (11.3\%) in men). At the same time, women had a higher class of angina than men (median (interquartile range) according to the Seattle Pain Questionnaire $80(70-100)$ vs. 90 (70-100)), but they had less severe ischemia in imaging stress tests (383 patients out of 919 (41.7\%) vs. 1361 out of 2972 (45.9\%) with severe ischemia; 386 patients out of 919 (42.0\%) vs. 1215 out of 2972 (40.9\%) with moderate ischemia; 150 patients out of 919 (16.4\%) vs. 394 out of 2972 (13.3\%) with or without mild ischemia). In addition, women had less extensive vascular lesion. Thus, three-vessel disease occurred in $36 \%$ of women and $47 \%$ of men; twovessel lesion - in 32 and $31 \%$ respectively; singlevessel disease in $31 \%$ of women and $22 \%$ of men. Female gender was independently associated with a higher incidence of angina attacks (OR 1.41; 95\% CI 1.13-1.76).

Thus, women who participated in the ISCHEMIA trial had a higher incidence of angina attacks, regardless of less severe ischemia according to imaging stress tests and more frequent single-vessel disease, compared to men. These results reflect the inherent gender differences in the complex relationships between angina, atherosclerosis, and myocardial ischemia, which are important for testing and treating patients with suspected stable ischemic heart disease [12].

Previous clinical studies that evaluated the effect of revascularization in patients with stable CHD have generally excluded patients with severe chronic kidney disease (CKD). In the ISCHEMIA-CKD study, 777 patients with advanced CKD and moderate to severe ischemia were randomized on stress testing for treatment using either an initial invasive strategy in combination with medical therapy, or an initial conservative strategy consisting only of medical therapy and angiography. The primary outcome (death or non-fatal MI) and the secondary outcomes (a com- 
Таким образом, у женщин, участвовавших в исследовании ISCHEMIA, отмечалась более высокая частота приступов стенокардии, независимо от менее тяжелой ишемии по данным визуализирующих стресс-тестов и более частого однососудистого поражения, по сравнению с мужчинами. Эти результаты отражают врожденные гендерные различия в сложных отношениях между стенокардией, атеросклерозом и ишемией миокарда, имеющих значение для тестирования и лечения пациентов с подозрением на стабильную ишемическую болезнь сердца [12].

Проводимые ранее клинические исследования, в которых оценивался эффект реваскуляризации у пациентов со стабильной ИБС, обычно исключали пациентов с тяжелой хронической болезнью почек (ХБП). В исследовании ISCHEMIA-CKD были рандомизированы 777 пациентов с тяжелым поражением почек и умеренной или тяжелой ишемией при стресстестировании для лечения с использованием либо начальной инвазивной стратегии в сочетании с медикаментозной терапией, либо первоначальной консервативной стратегии, состоящей только из медикаментозной терапии и ангиографии. Оценивались первичный исход - смерть или нефатальный ИМ и вторичные исходы: комбинированный показатель смерти, нефатального ИМ или госпитализации по поводу нестабильной стенокардии, сердечной недостаточности или успешная реанимация по поводу остановки сердца. При среднем периоде наблюдения 2.2 года первичный исход наступил у 123 пациентов при инвазивной стратегии и у 129 пациентов в группе консервативной стратегии (скорректированное отношение рисков 1.01; 95\% ДИ о.79-1.29; $p=0.95)$. Результаты для ключевого вторичного исхода были аналогичными (скорректированное отношение рисков 1.01; 95\% ДИ 0.79-1.29). Инвазивная стратегия была связана с более высокой частотой инсульта (отношение рисков 3.76; 95\% ДИ 1.52-9.32; $p=0.004)$ и с более высокой частотой смерти или начала диализа (отношение рисков 1.48; 95\% ДИ 1.04-2.11; $p=0.03)$, чем консервативная стратегия. Таким образом, у пациентов со стабильной ИБС, тяжелым поражением почек и умеренной или тяжелой ишемией не обнаружено преимуществ исходной инвазивной стратегии по сравнению с консервативной в отношении снижения риска смерти или нефатального инфаркта миокарда [13, 14].

В Рекомендациях Европейского общества кардиологов (ESC) 2019 г. по диагностике и наблюдению за больными хроническими коронар- posite of death, non-fatal MI, hospitalization for unstable angina, heart failure, resuscitatied cardiac arrest) were evaluated. With an average follow-up period of 2.2 years, the primary outcome occurred in 123 patients in the invasive strategy group and in 129 patients in the conservative strategy group (hazard ratio 1.01; 95\% CI 0.79-1.29; $p=0.95$ ). The results for the key secondary outcome were similar (hazard ratio 1.01; 95\% CI 0.79-1.29). The invasive strategy was associated with a higher incidence of stroke (hazard ratio 3.76; 95\% CI 1.52-9.32; $p=0.004)$ and a higher incidence of death or initiation of dialysis (hazard ratio 1.48; 95\% CI 1.04-2.11; $p=0.03$ ) than the conservative strategy. Thus, in patients with stable CHD, advanced CKD, and moderate or severe ischemia, there were no advantages of the initial invasive strategy compared to the conservative one in reducing the risk of death or non-fatal myocardial infarction [13, 14].

In the Guidelines of the European Society of Cardiology (ESC) 2019 for the diagnosis and management of chronic coronary syndromes, much attention is paid to the problem of myocardial ischemia in the so-called non-obstructive $(<50 \%$ luminal occlusion, or fractional flow reserve $>0.80$ ) coronary arteries lesion determined in about $70 \%$ of patients who underwent coronary angiography, and attracting the attention of both invasive and non-invasive cardiologists [2].

Such a lesion is more common in women, and patients with non-obstructive lesions are characterized by a wide range of symptoms that are often mistaken for non-cardiac manifestations, which leads to errors in the diagnosis and treatment. The main clinical and pathophysiological criteria for non-obstructive CA lesion are very diverse (Fig. 2).

Specific mechanisms leading to the formation of non-obstructive coronary arteries disease are also multifactorial and may be present in isolation or in combinations. These include:

- microvascular angina $-51 \%$;

- combination of microvascular and vasospastic angina $-21 \%$;

- vasospastic angina $-17 \%$;

- non-cardiac causes - $11 \%[4,5]$.

INOCA can develop due to coronary vasospasm, microcirculatory disorders, arterial hypertension, aortic stenosis, anemia, cardiomyopathy, heart failure, autoimmune diseases, vascular abnormalities, etc. and is not a seemingly favorable condition at a first glance [4, 5]. In patients with non-obstructive coronary arteries, despite the favorable prognosis, due to the presence of symptoms of angina, there is 


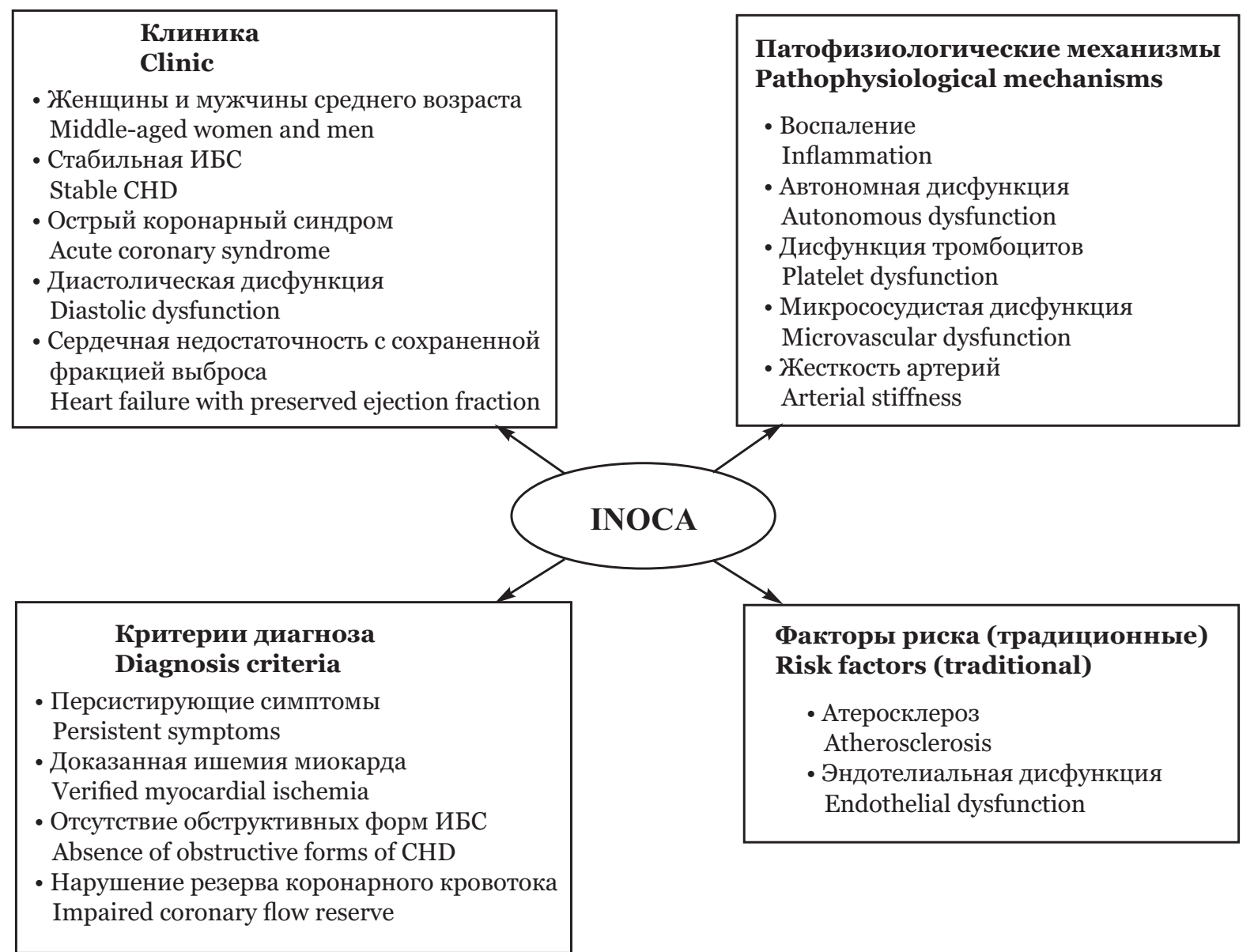

Рис. 2. Ишемия миокарда при необструктивном поражении коронарных артерий Fig. 2. Ischemia in non-obstructive coronary arteries

ными синдромами большое внимание уделено проблеме ишемии миокарда при так называемом необструктивном (<50 \% сужения просвета, или фракционном резерве коронарного кровотока >о.80) поражении коронарных артерий, определяющемся примерно у 70 \% пациентов при ангиографическом исследовании коронарных сосудов и привлекающем внимание как инвазивных, так и неинвазивных кардиологов [2].

Подобное поражение чаще встречается у женщин, при этом пациенты с необструктивным поражением характеризуются широким спектром симптомов, которые часто ошибочно принимаются за некардиальные проявления, что ведет к ошибкам в диагностике и лечении. Основные клинико-патофизиологические критерии необструктивного поражения КА весьма многообразны (рис. 2).

Конкретные механизмы, ведущие к формированию необструктивного поражения коронарных сосудов, являются также мультифакторными и могут присутствовать изолированно либо в комбинациях. К ним относятся: often low quality of life (QOL), which limits daily activity.

In comparison with the asymptomatic type of $\mathrm{CHD}$, non-obstructive lesion is associated with an increased occurrence of cardiovascular events, repeated hospitalizations, and a decrease in QOL. In comparison with unchanged coronary arteries $\mathrm{CHD}$, the non-obstructive CA lesion is associated with an increased risk of MI within a year, which was confirmed in a large-scale study that included data on all participants of the CART (Veterans Affairs Clinical Assessment, Reporting, and Tracking System) Program, who in the period 2007-2012 had were performed an elective coronary angiography in connection with the suspected coronary heart disease [15]. The prerequisite for the study was that in non-obstructive forms of CHD, atherosclerotic plaques (AP) in the CA are less likely to lead to a disturbance in coronary flow or symptoms of angina, and therefore in the medical literature these changes are referred to as "clinically insignificant CHD". However, this attitude to non-obstructive CHD may be incorrect, since the results of pre- 
- микроваскулярная стенокардия - 51 \%;

- сочетание микроваскулярной и вазоспастической стенокардии - $21 \%$;

- вазоспастическая стенокардия - $17 \%$;

- некардиальные причины - $11 \%[4,5]$.

INOCA может развиться вследствие коронарного вазоспазма, микроциркуляторных нарушений, артериальной гипертонии, аортального стеноза, анемии, кардиомиопатии, сердечной недостаточности, аутоиммунных болезней, сосудистых аномалий и т.д. и не является кажущимся на первый взгляд благоприятным состоянием $[4,5]$. У пациентов с необструктивным поражением коронарных артерий, несмотря на благоприятный прогноз, из-за наличия симптомов стенокардии нередко отмечается низкое качество жизни (КЖ), лимитирующее ежедневную активность.

В сравнении с бессимптомным вариантом ИБС необструктивное поражение ассоциируется с повышенной частотой кардиоваскулярных событий, повторными госпитализациями, снижением КЖ. В сравнении с ИБС с неизмененными коронарными артериями необструктивное поражение КА ассоциируется с повышенным риском развития в течение одного года ИМ, что было подтверждено в крупномасштабном исследовании, включавшем данные обо всех участниках программы CART (Veterans Affairs Clinical Assessment, Reporting, and Tracking System), которым в период 2007-2012 гг. выполнялась плановая коронароангиография в связи с предполагаемой коронарной болезнью сердца (КБС) [15]. Предпосылкой к проведению исследования послужило то, что при необструктивных формах КБС атеросклеротические бляшки (АБ) в КА реже приводят к нарушению коронарного кровотока или симптомам стенокардии, в связи с чем в медицинской литературе эти изменения обозначаются термином «клинически незначимая КБС». Однако такое отношение к необструктивной КБС может быть неправильным, поскольку результаты ранее выполненных исследований свидетельствовали о том, что большинство случаев разрыва АБ с развитием ИМ касалось бляшек, которые не обусловливали обструкцию КА $[16,17]$.

Почти все регистры, в которых учитывались результаты компьютерной ангиографии (КАГ), включали только данные о больных КБС и обструктивными поражениями КА. В ранее опубликованных регистрах, включавших данные о больных с необструктивной КБС, проспективно не оценивали частоту развития неблагоприятных клинических исходов. Целью программы CART была проверка гипотезы о том, что прогрессиро- vious studies indicated that the majority of cases of the AP rupture with the development of MI, concerned plaques that did not cause CA obstruction $[16,17]$.

Almost all the registries that took into account the results of computed angiography (CAG) included only data on patients with CHD and obstructive CA lesions. Previously published registries that included data on patients with non-obstructive CHD did not prospectively assess the incidence of adverse clinical outcomes. The aim of the CART Program was to test the hypothesis that the progression of CHD from non-obstructive to obstructive forms is accompanied by a gradual increase in the incidence of MI and mortality. According to standard definitions, non-obstructive CHD was diagnosed with of 20-50\% stenosis of the left main CA or with 20$70 \%$ stenosis of any other epicardial artery. Obstructive CHD was diagnosed with large lesion volumes, and the absence of CHD - in stenosis of less than $20 \%$ or the presence of the CA luminal surface roughness only.

Of the 37674 examined patients, non-obstructive and obstructive CHD were diagnosed in 22.3 and $55.4 \%$ of patients respectively. Within one year, 385 and 845 patients died or were hospitalized for MI in two groups. In the absence of obvious signs of $\mathrm{CHD}$, the incidence of MI during the year with nonobstructive lesions was $0.11 \%$ and increased progressively with one CA lesion up to $0.24 \%$, with two CA lesions up to $0.56 \%$, and with three CA lesions up to $0.59 \%$. In obstructive CHD, the incidence of MI in one CA lesion reached $1.18 \%$, in two CA lesions $-2.18 \%$, and in three CA lesions $-2.47 \%$. In addition, the presence of non-obstructive CHD compared to the absence of CHD was accompanied by a significant increase in the risk of MI and death during a year. This suggests the clinical significance of non-obstructive CHD and makes it necessary to conduct further studies on the effectiveness of interventions aimed at improving the prognosis in such patients.

The stages of management of non-obstructive coronary arteries patients include lifestyle modification and antianginal therapy. The latter is represented by beta-blockers, calcium channel-blocking agents (CCBA), nicorandil, ranolazine, ivabradine and trimetazidine in microvascular angina and CCBA, prolonged nitrates and nicorandil in vasospastic angina [18]. It should be noted, however, that the treatment of such patients is still carried out in a clearly insufficient volume and the frequency of prescribing basic drugs did not exceed 50\%, as R. Her- 
вание КБС от необструктивных до обструктивных форм сопровождается постепенным увеличением частоты развития ИМ и общей смертности. В соответствии со стандартными определениями, необструктивная КБС диагностировалась при стенозе 20-50 \% ствола левой КА или 20-70 \% при поражении любой другой эпикардиальной артерии. Обструктивную КБС диагностировали при больших объемах поражения, а отсутствие КБС определяли при стенозе менее 20 \% или наличии лишь неровности контуров просвета КА.

Из 37674 обследованных необструктивная и обструктивная КБС диагностировались у 22.3 и 55.4 \% пациентов соответственно. В течение одного года в двух группах умерли или были госпитализированы по поводу ИМ 385 и 845 больных. В отсутствие явных признаков КБС частота развития ИМ в течение года при необструктивном поражении составила $0.11 \%$ и увеличивалась прогрессивно при поражении одной КА - до $0.24 \%$, при поражении двух КА - до 0.56 \% и при поражении трех КА - до 0.59\%. При обструктивной КБС частота ИМ при поражении одной КА достигала 1.18 \%, при поражении двух КА $2.18 \%$ и при поражении трех КА $-2.47 \%$. Кроме того, наличие необструктивной КБС по сравнению с отсутствием КБС сопровождалось значимым увеличением риска развития ИМ и смерти в течение года. Это позволяет предположить клиническую значимость необструктивной КБС и обусловливает необходимость проведения дальнейших исследований эффективности вмешательств, направленных на улучшение прогноза у таких больных.

Этапы ведения больных необструктивными поражениями коронарных артерий включают модификацию образа жизни и антиангинальную терапию. Последняя представлена бета-адреноблокаторами, блокаторами медленных кальциевых каналов (БМКК), никорандилом, ранолазином, ивабрадином и триметазидином при микрососудистой стенокардии и БМКК, пролонгированными нитратами и никорандилом при вазоспастической стенокардии [18]. Следует, однако, заметить, что лечение таких пациентов до настоящего времени осуществлялось в явно недостаточном объеме и частота назначения базисных препаратов не превышала 50 \%, что продемонстрировали в своем обзоре R. Herscovici et al. [19] (табл. 1).

В связи со значимостью изложенного выше в 2020 г. опубликован Согласительный документ экспертов по проблеме INOCA [18], в котором обсуждаются вопросы возникновения стенокардии scovici et al. demonstrated in their review [19] (Table 1).

Due to the significance of the above, the EAPCI Expert Consensus Document on Ischemia with INOCA was published in 2020 [18], which discusses the occurrence of angina in non-obstructive coronary arteries, including those associated with microvascular lesions, diagnosis and treatment of this condition.

\section{CONCLUSION}

The selection of patients with stable CHD for invasive treatment should be carried out as carefully as possible, taking into account the severity of angina, possibilities of modern antianginal therapy, and the fact that PCI does not improve the prognosis, in contrast to optimal medical therapy.

Non-obstructive CA disease, although not accompanied by significant stenosis or total occlusion of the vessels' lumen by atherosclerotic plaque, is associated with endothelial dysfunction, coronary vasospasm, microvascular dysfunction or congenital anomalies, as a result of which it may be accompanied by the same symptoms as obstructive lesion. The high rate and clinical significance of non-obstructive coronary artery disease requires the search for new diagnostic methods, verification of risk factors, causes, and optimal treatment approaches. Management of myocardial ischemia with non-obstructive CA patients should be carried out on the basis of the 2020 EAPCI Expert Consensus Document on Ischemia with INOCA.

Conflict of interest. The authors declare no conflict of interest.

при необструктивном поражении сосудов, в том числе на фоне микрососудистого поражения, диагностики и лечения данного состояния.

\section{ЗАКЛЮЧЕНИЕ}

Отбор пациентов со стабильной ИБС для инвазивного лечения следует осуществлять максимально тщательно, принимая во внимание тяжесть стенокардии, возможности современной антиангинальной терапии и то, что ЧКВ не улучшает прогноз в отличие от оптимальной медикаментозной терапии.

Необструктивное поражение КА, хоть и не сопровождается существенным сужением или закрытием просвета сосудов артерий атеросклеротической бляшкой, связано с эндотелиальной 
Таблица 1. Частота назначения базисных препаратов больным INOCA, \%

Table 1. Cardiovscular treatment rates in INOCA patients, \%

\begin{tabular}{lll}
\hline $\begin{array}{l}\text { Aвтор, год публикации }(n) \\
\text { Author, publication year }(n)\end{array}$ & $\begin{array}{l}\text { Антигипертензивные/антиангинальные препараты } \\
\text { Antihypertensive/antianginal agents }\end{array}$ & $\begin{array}{l}\text { Статины } \\
\text { Statins }\end{array}$ \\
\hline Maddox, 2010 $(n=237167)$ & 51 & 47 \\
Johnston, 2011 $(n=5386)$ & $21 / 56$ & 51 \\
Shaw, 2011 $(n=824)$ & $10 / 20$ & 32 \\
Jespersen, 2012 $(n=5183)$ & 44 & 50 \\
Sedlak, 2012 $(n=1864)$ & 34 & 32 \\
Sharaf, 2013 $(n=567)$ & $2 / 39$ & $10^{\star} / 31^{*}$ \\
Chow, 2015 $(n=10418)$ & Нет данных / No data & 33.3 \\
Nielsen, $2017(n=14$ 205) & $11.8 / 32.3$ & $25 / 39.2$ \\
Galway, $2017(n=2642)$ & $18 / 46$ & $34-59$ \\
\hline
\end{tabular}

^Коронарные артерии в норме.

Normal coronary arteries.

*Необструктивное поражение коронарных артерий.

Non-obstructive coronary artery disease.

дисфункцией, коронарным вазоспазмом, микроваскулярной дисфункцией или врожденными аномалиями, вследствие чего может сопровождаться такими же симптомами, как и обструктивное. Высокая частота и клиническая значимость необструктивного поражения коронарных артерий требует поиска новых диагностических методик, верификации факторов риска, причин

\section{СПИСОК ЛИТЕРАТУРЫ}

1. Андреенко Е.Ю., Явелов И.С., Лукьянов М.М. и др. Ишемическая болезнь сердца у лиц молодого возраста: особенности этиологии, клинических проявлений и прогноза // Кардиология. 2018. Т. 58, № 11. C. 24-34.

2. Рекомендации ESC по диагностике и лечению хронического коронарного синдрома / Рос. кардиол. журн. 2020. T. 25, № 2. С. 119-180.

3. Бойцов С.А., Погосова Н.В., Бубнова М.Г. и др. Кардиоваскулярная профилактика 2017. Российские национальные рекомендации // Рос. кардиол. журн. 2018. T. 23, № 6. С. 7-122.

4. Taqueti V.R. Coronary microvascular dysfunction in vasospastic angina: provocative role for the microcirculation in macrovessel disease prognosis // J. Am. Coll. Cardiol. 2019. Vol. 74 (19). P. 2361-2364.

5. Aziz A., Hansen H.S., Sechtem U., Ong P. Sex-related differences in vasomotor function in patients with angina and unobstructed coronary arteries // J. Am. Coll. Cardiol. 2017. Vol. 70 (19). P. 2349-2358.

6. Аронов Д.М., Лупанов В.П. Исследование COURAGE: обескураживают или воодушевляют его результаты? // Кардиоваск. терапия и профилактика. 2007. Т. 7, № 7. С. 95-104.

7. Maron D.J., Mancini G.B., Hartigan P.M. et al. Healthy behavior, risk factor control, and survival in the COURAGE trial // J. Am. Coll. Cardiol. 2018. Vol. 72 (19). P. 2297-2305. doi: 10.1016/j.jacc.2018.08.2163. и оптимальных подходов к лечению. Ведение больных с ишемией миокарда на фоне необструктивного поражения КА должно осуществляться на основе материалов Согласительного документа экспертов по проблеме INOCA 2020 г.

Конфликт интересов. Авторы заявляют об отсутствии конфликта интересов.

\section{REFERENCES}

1. Andreenko E.Yu., Yavelov I.S., Loukianov M.M. et al. (2018). Ischemic heart disease in subjects of young age: current state of the problem. Features of etiology, clinical manifestation and prognosis. Cardiology, 58, 11, 24-34.

2. 2019 ESC Guidelines for the diagnosis and management of chronic coronary syndromes (2020). Russian Journal of Cardiology, 25, 119-180.

3. Boytsov S.A., Pogosova N.V., Bubnova M.G. et al. (2018). Cardiovascular prevention 2017. National Guidelines. Russian Journal of Cardiology, 23, 6, 7-122. In Russ.

4. Taqueti V.R. (2019). Coronary microvascular dysfunction in vasospastic angina: provocative role for the microcirculation in macrovessel disease prognosis. J. Am. Coll. Cardiol., 74 (19), 2361-2364.

5. Aziz A., Hansen H.S., Sechtem U., Ong P. (2017). Sexrelated differences in vasomotor function in patients with angina and unobstructed coronary arteries. J. Am. Coll. Cardiol., 70 (19), 2349-2358.

6. Aronov D.M., Lupanov V.P. (2007). COURAGE study results: disappointing or encouraging? Cardiovascular Therapy and Prevention, 7, 7, 95-104.

7. Maron D.J., Mancini G.B., Hartigan P.M. et al. (2018). Healthy behavior, risk factor control, and survival in the COURAGE trial. J. Am. Coll. Cardiol., 72 (19), 2297-2305. doi: 10.1016/j.jacc.2018.08.2163. 
8. Maron D.J., Hochman J.S., O'Brien S.M. et al. International Study of Comparative Health Effectiveness with Medical and Invasive Approaches (ISCHEMIA) trial: Rationale and design // Am. Heart J. 2018. Vol. 201. P. 124-135. doi: 10.1016/j.ahj.2018.04.011.

9. Maron D.J., Hochman J.S., Reynolds H.R. et al. Initial invasive or conservative strategy for stable coronary disease // N. Engl. J. Med. 2020. Vol. 382 (15). P. 1395-1407.

10. Spertus J.A., Jones P.G., Maron D.J. et al. Health-status outcomes with invasive or conservative care in coronary disease // N. Engl. J. Med. 2020. Vol. 382 (15). P. 1408-1419.

11. Newman J.D., Alexander K.P., Gu X. et al. Baseline predictors of low-density lipoprotein cholesterol and systolic blood pressure goal attainment after 1 year in the ISCHEMIA trial // Circ. Cardiovasc. Qual. Outcomes. 2019. Vol. 12 (11): eoo6oo2.

12. Reynolds H.R., Shaw L.J., Min J.K. et al. Association of sex with severity of coronary artery disease, ischemia, and symptom burden in patients with moderate or severe ischemia: secondary analysis of the ISCHEMIA randomized clinical trial // JAMA Cardiol. 2020. Vol. 5 (7). P. 773-786. doi: 10.1001/jamacardio.2020.0822.

13. Bangalore S., Maron D.J., O'Brien S.M. et al. Management of coronary disease in patients with advanced kidney disease // N. Engl. J. Med. 2020. Vol. 382 (17). P. 1608-1618. doi: 10.1056/NEJMoa1915925.

14. Bangalore S., Maron D.J., Fleg J.L. et al. International study of comparative health effectiveness with medical and invasive approaches - chronic kidney disease (ISCHEMIA-CKD): Rationale and design // Am. Heart J. 2018. Vol. 205. P. 45-52. doi: 10.16/j.hj.2018.07.023.

15. Bradley S.M., O’Donnell C. I., Grunwald G.K. et al. Facility-level variation in hospitalization, mortality, and costs in the 30 days after percutaneous coronary intervention: insights on short-term healthcare value from the Veterans Affairs Clinical Assessment, Reporting, and Tracking System (VA CART) Program // Circulation. 2015. Vol. 132 (2). P. 101-108. doi: 10.1161/CIRCULATIONAHA.115.015351.

16. Bairey Merz C.N., Pepine C.J., Walsh M.N., Fleg J.L. Ischemia and no obstructive coronary artery disease (INOCA): Developing evidence-based therapies and research agenda for the next decade // Circulation. 2017. Vol. 135 (11). P. 1075-1092.

17. SucatoV., Novo G., Saladino A. et al. Ischemia in patients with no obstructive coronary artery disease: classification, diagnosis and treatment of coronary microvascular dysfunction // Coron. Artery Dis. 2020. Vol. 31 (5). P. 472-476. doi: 10.1097/MCA.000000000000085.

18. Kunadian V., Chieffo A., Camici P.G. et al. An EAPCI Expert Consensus Document on ischaemia with nonobstructive coronary arteries in collaboration with European Society of Cardiology Working Group on Coronary Pathophysiology \& Microcirculation endorsed by Coronary Vasomotor Disorders International Study Group // EuroIntervention. 2020. Vol. 16 (13). P. 1049-1069. doi: 10.4244/EIJY20Mo7_01.

19. Herscovici R., Sedlak T., Wei J. et al. Ischemia and no Obstructive Coronary Artery Disease (INOCA): What is the risk? // J. Am. Heart Assoc. 2018. Vol. 7 (17): yoo8868. doi: 10.1161/JAHA.118.008868.
8. Maron D.J., Hochman J.S., O’Brien S.M. et al. (2018). International Study of Comparative Health Effectiveness with Medical and Invasive Approaches (ISCHEMIA) trial: Rationale and design. Am. Heart J., 201, 124-135. doi: 10.1016/j.ahj.2018.04.011.

9. Maron D.J., Hochman J.S., Reynolds H.R. et al. (2020). Initial invasive or conservative strategy for stable coronary disease. N. Engl. J. Med., 382 (15), 1395-1407.

10. Spertus J.A., Jones P.G., Maron D.J. et al. (2020). Health-status outcomes with invasive or conservative care in coronary disease. N. Engl. J. Med., 382 (15), 1408-1419.

11. Newman J.D., Alexander K.P., Gu X. et al. (2019). Baseline predictors of low-density lipoprotein cholesterol and systolic blood pressure goal attainment after 1 year in the ISCHEMIA trial. Circ. Cardiovasc. Qual. Outcomes, 12 (11): eoo6002.

12. Reynolds H.R., Shaw L.J., Min J.K. et al. (2020). Association of sex with severity of coronary artery disease, ischemia, and symptom burden in patients with moderate or severe ischemia: secondary analysis of the ISCHEMIA randomized clinical trial. JAMA Cardiol. 5 (7), 773-786. doi: 10.1001/jamacardio.2020.0822.

13. Bangalore S., Maron D.J., O’Brien S.M. et al. (2020). Management of coronary disease in patients with advanced kidney disease. N. Engl. J. Med., 382 (17), 1608-1618. doi: 10.1056/NEJMoa1915925.

14. Bangalore S., Maron D.J., Fleg J.L. et al. (2018). International study of comparative health effectiveness with medical and invasive approaches - chronic kidney disease (ISCHEMIA-CKD): Rationale and design. Am. Heart J., 205, 45-52. doi: 10.16/j.ahj.2018.07.023.

15. Bradley S.M., O’Donnell C.I., Grunwald G.K. et al. (2015). Facility-level variation in hospitalization, mortality, and costs in the 30 days after percutaneous coronary intervention: insights on short-term healthcare value from the Veterans Affairs Clinical Assessment, Reporting, and Tracking System (VA CART) Program. Circulation, 132 (2), 101-108. doi: 10.1161/CIRCULATIONAHA.115.015351.

16. Bairey Merz C.N., Pepine C.J., Walsh M.N., Fleg J.L. (2017). Ischemia and no obstructive coronary artery disease (INOCA): Developing evidence-based therapies and research agenda for the next decade. Circulation, 135 (11), 1075-1092.

17. Sucato V., Novo G., Saladino A. et al. (2020). Ischemia in patients with no obstructive coronary artery disease: classification, diagnosis and treatment of coronary microvascular dysfunction. Coron. Artery Dis., 31 (5), 472-476. doi: 10.1097/MCA.00ooooooooooo85.

18. Kunadian V., Chieffo A., Camici P.G. et al. (2020). An EAPCI Expert Consensus Document on ischaemia with non-obstructive coronary arteries in collaboration with European Society of Cardiology Working Group on Coronary Pathophysiology \& Microcirculation endorsed by Coronary Vasomotor Disorders International Study Group. EuroIntervention, 16 (13), 1049-1069. doi: 10.4244/EIJY20Mo7_01.

19. Herscovici R., Sedlak T., Wei J. et al. (2018). Ischemia and no Obstructive Coronary Artery Disease (INOCA): What is the risk? J. Am. Heart Assoc., 7 (17): yoo8868. doi: 10.1161/JAHA.118.008868. 


\section{СВЕДЕНИЯ ОБ АВТОРАХ}

Яхонтов Давыд Александрович - д-р мед. наук, профессор кафедры фармакологии, клинической фармакологии и доказательной медицины ФГБОУ ВО «Новосибирский государственный медицинский университет» Минздрава России.

Останина Юлия Олеговна - канд. мед. наук, доцент кафедры фармакологии, клинической фармакологии и доказательной медицины ФГБОУ ВО «Новосибирский государственный медицинский университет» Минздрава России.

О бра зец цитирования : Яхонтов Д.А., Останина Ю.О. Исследование ISCHEMIA. Взаимоотношение консервативного и интервенционного подходов к лечению стабильной ишемической болезни сердца. Ишемия миокарда при необструктивном поражении коронарных артерий (INOCA) // Journal of Siberian Medical Sciences. 2021. № 2. C. 114-126.

\section{ABOUT THE AUTHORS}

Yahontov Davyd Alexandrovich - Dr. Sci. (Med.), Professor, Department of Pharmacology, Clinical Pharmacology and Evidence-Based Medicine, Novosibirsk State Medical University.

Ostanina Juliya Olegovna - Cand. Sci. (Med.), Associate Professor, Department of Pharmacology, Clinical Pharmacology and Evidence-Based Medicine, Novosibirsk State Medical University.

Citation example: Yakhontov D.A., Ostanina Yu.O. (2021). ISCHEMIA trial. The relationship between medical and interventional approach to stable ischemic heart disease treatment. Myocardial ischemia with non-obstructive coronary arteries (INOCA). Journal of Siberian Medical Sciences, 2, 114-126. 